\title{
Analisis Ketertarikan Generasi Milenial pada Longform Journalism Visual Interaktif Kompas
}

\author{
Desy Kristi Yanti, Eko Harry Susanto \\ desikristinababan@gmail.com,ekos@fikom.untar.ac.id \\ Fakultas Ilmu Komunikasi Universitas Tarumanagara
}

\begin{abstract}
In 2016, Kompas initiated a new journalistic product, namely news writing, a type of longform journalism called Visual Interactive Compass (VIK). This platform is designed in such a way as to present in-depth news writing and enriched with interactivity elements from the multimedia aspect. Millennials are one of the young generation who live in the digital era and online networks. The Indonesian Internet Service Providers Association (APJII) declared this generation as the most internet users as of October 2016. The purpose of this study is to find out how millennial generation is interested in VIK through four aspects, namely modality, accessability, interactivity, navigability. This research is a descriptive qualitative research with case study method. Data collection techniques in this study used in-depth interviews, literature studies, and also online data search. The results of this study are changes in the form of in-depth news writing type preferred by the millennial generation, VIK longform journalism news presentation is considered informative and interesting with multimedia elements by millennials, and millennial generation is proven in daily use of gadgets, as well as finding information.
\end{abstract}

Keywords: interactivity, longform journalism, millennial generation, visual interactive compass.

\begin{abstract}
Abstrak
Di Tahun 2016, Kompas menggagas sebuah produk jurnalistik baru yaitu penulisan berita jenis longform journalism yang diberi nama Visual Interaktif Kompas (VIK). Platform ini dirancang sedemikian rupa untuk menyajikan tulisan berita yang mendalam dan diperkaya dengan unsur interaktivitas dari aspek multimedia. Kaum Milenial merupakan salah satu generasi muda yang hidup dalam era digital serta jaringan online. Asosiasi Penyelenggara Jasa Internet Indonesia (APJII) menyatakan generasi ini sebagai pengguna Internet terbanyak per Oktober 2016. Tujuan dari penelitian ini ingin mengetahui bagaimana ketertarikan generasi milenial pada VIK melalui empat aspek yaitu modality, accessibility, interactivity, navigability. Penelitian ini merupakan penelitian kualitatif deskriptif dengan metode studi kasus. Teknik pengumpulan data dalam penelitian ini menggunakan wawancara mendalam, studi pustaka, dan juga penelusuran data online. Hasil dari penelitian ini adalah perubahan bentuk penulisan berita mendalam jenis longform disukai oleh generasi milenial, penyajian berita longform journalism VIK dinilai informatif serta menarik dengan unsur multimedia oleh milenial, dan generasi milenial terbukti dalam kesehariannya selalu menggunakan gadget, begitu juga dalam hal mencari informasi.
\end{abstract}

Kata Kunci: generasi milenial, interaktivitas, longform journalism, visual interaktif kompas, 


\section{Pendahuluan}

Di era digital, media massa berkembang mengikuti kemajuan teknologi dengan menghadirkan media online. Media baru adalah tempat saluran pesan komunikasi terdesentralisasi yakni, distribusi pesan lewat satelit meningkat, penggunaan jaringan kabel dan komputer; semakin seringnya terjadi komunikasi interaktif (dua sisi), juga meningkatnya derajat fleksibilitas untuk menentukan bentuk dan konten melalui digitalisasi dari pesan (Paramita, Erdiansyah, 2016). Praktik jurnalisme yang ada saat ini berupa laporan pemberitaan dalam bentuk penulisan berita yang singkat, dan permasalahan yang ada tidak dibahas secara mendalam. Di tahun 2012, salah satu tulisan longform journalism karya John Branch yang berjudul, "Snow-Fall: The Avalanche at Tunnel Creek" yang dipublikasikan oleh The New York Times dalam situs websitenya, nytime.com berhasil menyita perhatian para ilmuan maupun praktisi jurnalisme. Tulisan tersebut mengusung karakteristik jurnalisme multimedia longform. Sementara di Indonesia, tren longform journalism ini telah diadopsi oleh salah satu media online ternama, yaitu Kompas yang memproduksi Visual Interaktif Kompas. Generasi Milenial, istilah generasi ini (dalam Budiati, dkk 2018: 16) pertama kali dicetuskan oleh William Strauss dan Neil dalam bukunya yang berjudul Millennials Rising: The Next Generation (2000). Generasi milenial yang dikenal dengan generasi Y merupakan generasi yang lahir di tahun 1980 - awal tahun 2000. Saat ini, generasi milenial merupakan generasi muda yang usianya sekitar 18-38 tahun dan hidup dalam dunia yang penuh fasilitas elektronik serta jaringan online.Berdasarkan hasil survey dari Asosiasi Penyelenggara Jasa Internet Indonesia (APJII) per Oktober 2016 mencatat, pengguna Internet di Indonesia didominasi generasi milenial. $80 \%$ atau sekitar 25 juta pengguna internet berusia (25-29 tahun) dan sekitar $72 \%$ pengguna berusia (30-34 tahun). Berdasarkan latar belakang diatas, maka penulis tertarik untuk melakukan penelitian VIK yang memiliki karakteristik condong pada generasi milenial.

\section{Metode Penelitian}

Penelitian ini menggunakan pendekatan penelitian kualitatif. Metode penelitian yang digunakan dalam penelitian ini adalah studi kasus Robert K.Yin. Menurut Yin, 2015 (dalam Yazan, 2015:138), studi kasus merupakan penelitian empiris yang menyelidiki suatu kasus dengan berlandaskan pada pertanyaan "mengapa" dan "bagaimana" mengenai suatu fenomena sosial. Penelitian studi kasus dapat dibedakan menjadi tiga tipe, yaitu studi kasus eksplanatoris, eksploratoris dan deskriptif. Penelitian dengan tipe deskriptif berguna untuk menggambarkan sebuah fenomena menggunakan berbagai sumber data (Yin, 2015:1-5). Penelitian ini menggunakan tipe deskriptif karena peneliti ingin mengetahui produk jurnalistik bentuk longform journalism VIK pada generasi milenial yang akan dijelaskan sesuai dengan klasifikasi model MAIN.

\section{Hasil Temuan dan Diskusi}

Dalam penelitian ini, peneliti akan membahas faktor yang menjadi ketertarikan Generasi Milenial pada Longform journalism Visual Interaktif Kompas. Berdasarkan temuan data yang telah peneliti dapatkan, diperoleh hasil sebagai berikut: 


\section{Perubahan berita Longform Journalism lebih mendalam}

Pada pembahasan pertama penulis meneliti perubahan bentuk penulisan berita ke dalam longform journalism memiliki informasi yang lebih mendalam dan memiliki cara penyampaian yang lebih naratif. William selaku informan mengatakan bahwa berita jenis longform journalism menyampaikan informasi yang panjang namun dijelaskan secara mendalam, dan penulisan beritanya memiliki alur yang bersifat naratif. Sama halnya dengan narasumber atau informan lain dari pembaca longform journalism VIK yang juga menyukai inovasi baru ini karena bentuk penyajian beritanya yang lebih mendalam dan seperti bercerita, hal ini sesuai dengan aspek modality

Sejalan dengan teori longform journalism, tidak sama dengan penulisan berita yang ada di media online pada umumnya, bentuk penulisan berita longform lebih mendalam dan panjang, serta disajikan dengan unsur - unsur multimedia yang menarik (LassilaMerisalo, 2014).

Dengan demikian dapat dikatakan penulisan berita jenis longform journalism ini merupakan suatu hal yang berbeda dan menarik di kalangan generasi milenial, karena isi beritanya yang lebih mendalam, jelas dan alur penulisannya yang naratif lebih mudah dipahami oleh generasi milenial.

\section{Penyajian informasi pada platform VIK beragam dengan karakter multimedia}

Selain bentuk penulisan pada berita jenis longform journalism yang mendalam dan bersifat naratif, hal lainnya yang menjadi ketertarikan generasi milenial pada longform journalism adalah informasi yang disampaikan dari berbagai bidang dan unsur interaktivitas dari multimedia yang sangat ditonjolkan, seperti yang dilakukan oleh longform journalism pada Visual Interaktif Kompas (VIK). Martin Lister, dkk (2009) menyatakan bahwa salah satu karakteristik dari media online adalah interaktivitas, yaitu pengguna dimampukan untuk terlibat secara langsung dan merubah gambar dan teks yang diakses.

Sejalan dengan pernyataan yang disampaikan oleh Laksono Hariwiwoho, selaku Wakil Redaktur Pelaksana Kompas.com bahwa VIK berbeda dengan tulisan panjang berupa laporan investigasi atau laporan indepth yang ada pada media online. Longform journalism pada Visual Interaktif Kompas lebih membahas kepada hal apapun, sehingga beragam informasi yang disampaikan oleh VIK kepada pembaca. Hal yang paling menonjol dari VIK ialah interaktivitas dari unsur multimedia yang dimiliki. Dengan unsur-unsur multimedia VIK dikembangkan dan dikemas sedemikian rupa menjadi sajian yang lebih menarik dan interaktif menyesuaikan generasi milenial saat ini yang selalu mengkonsumsi gadget. Dalam hal ini interaktif yang dimaksudkan ialah, pembaca bisa merasakan interaksi dengan sistem yang ada pada VIK, seperti membaca sambil melihat gambar ilustrasi burung yang bergerak terbang, infografik yang dapat dipencet dengan tombol, bermain games sesuai topik artikel, dan lainnya.

Pernyataan Wakil Redaktur Pelaksana Kompas.com tersebut dibenarkan oleh informan umum yang merupakan generasi milenial. William, salah satu generasi yang kesehariannya mencari berita di media online mengatakan bahwa VIK sangat menampilkan unsur interaktivitas dari multimedianya. Website VIK bukan lagi hanya tulisan, tetapi dilengkapi video, peta yang bisa di zoom, gambar animasi, ada games, tampilan layoutnya juga eksklusif dan menarik, hal ini merupakan bagian dari aspek modality dan interactivity. 
Dengan demikian dapat dikatakan bahwa sisi interaktivitas yang ditonjolkan longform journalism pada Visual Interaktif Kompas menjadi daya tarik bagi generasi milenial. Unsur - unsur multimedia yang dimasukan dalam longform journalism sesuai dengan karakter generasi milenial yang lebih suka pada aspek audio - visual ketimbang hanya teks saja.

\section{Generasi milenial erat dengan media digital dan menyukai informasi dengan unsur audio-visual}

Dengan adanya inovasi internet, masyarakat kini lebih suka menyentuh atau menggunakan tombol-tombol layar seperti gadget. Salah satunya ialah, generasi milenial, kaum yang hidup di era kemajuan teknologi, dan sangat mudah sekali paham soal teknologi. Di era digital saat ini, generasi milenial semakin banyak mengkonsumsi media digital. Tidak hanya untuk berkomunikasi atau melakukan aktivitas lainnya, tetapi juga mencari sumber informasi.

Karakteristik milenial yang selalu ingin cepat dan tertarik pada hal-hal baru yang menarik membuat milenial memanfaatkan gadget untuk mencari informasi di media online, dengan menggunakan jaringan internet. Tidak hanya itu, milenial juga memilih dalam membaca sebuah tulisan berita, kaum ini lebih suka membaca tulisan yang dipadukan dengan foto, video bahkan unsur - unsur multimedia lainnya yang bisa menarik perhatian mereka. Karakteristik generasi millennial dalam mengakses informasi antara lain: milenial menjadikan media sosial sebagai sumber informasi utama, kurang menyukai informasi yang mengandung banyak teks, konsumen informasi yang variatif (Viranda, dkk, 2018)

Hal tersebut sejalan dengan yang disampaikan oleh Albertus Magnus Prestianta, S.IKom., M.A, selaku Dosen Fakultas Ilmu Komunikasi, Universitas Multimedia Nusantara yang mengatakan bahwa, generasi milenial adalah generasi yang berbeda dari generasi sebelum maupun setelahnya. Generasi ini hidup di jaman serba teknologi, sehingga kesehariannya erat dengan media digital. Kaum ini juga sangat cepat beradaptasi dengan kemajuan dan perkembangan teknologi. Ia juga mengatakan bahwa dalam hal mencari informasi, generasi ini akan mencari cara yang lebih praktis, antara lain melalui gadget yang sudah menjadi bagian dari aktivitas sehari - harinya.

Begitu juga dengan para informan yang merupakan generasi milenial mengungkapkan bahwa hampir setiap hari mereka mengkonsumsi gadget, dan mencari informasi di media online melalui gadget. Hal tersebut karena, gadget memiliki jaringan yang cepat dan tidak rumit dalam mengaksesnya. Media online juga menjadi pilihan generasi ini karena, media online memiliki unsur interaktivitas dalam sistemnya yang sesuai dengan karakter generasi milenial dalam mencari informasi berita.

\section{Simpulan}

Perubahan bentuk penulisan berita jenis longform journalism di beberapa media online Indonesia seperti Kompas.com disukai oleh generasi milenial, sebab hal ini merupakan sesuatu yang baru bagi kaum milenial. Bentuk penulisan pada longform journalism lebih jelas, mendalam, serta menggunakan kalimat naratif , sehingga memberi kesan seperti bercerita. Berbeda dengan berita yang pada umumnya ditayangkan oleh media online. Inovasi ini dapat mengedukasi pembaca dengan cara penyampaian yang menarik. 
Penyajian berita longform journalism di Virtual Interaktif Kompas (VIK) dinilai informatif oleh kaum milenial, karena memiliki informasi beragam yang datang dari berbagai bidang, seperti lifestyle, kuliner, traveling, politik, ekonomi dan lainnya. Sementara, tampilan layout pada VIK dinilai oleh kaum milenial sangat menarik, karena menonjolkan unsur multimedianya.

Generasi milenial dalam kesehariannya selalu menggunakan gadget dan mudah beradaptasi dengan teknologi. Dengan gadget, milenial dapat mengakses media online dengan cepat untuk mendapatkan informasi. Dalam mencari informasi, milenial tak hanya mementingkan kecepatan tetapi juga unsur audio - visual seperti foto, dan video.

\section{Ucapan Terima Kasih}

Puji dan syukur kepada Tuhan Yang Maha Esa atas segala berkat dan rahmatNya, sehingga peneliti dapat melaksanakan kegiatan penelitian dan menyelesaikan penulisan laporan akhir skripsi ini yang berjudul "Analisis Ketertarikan Generasi Milenial pada Longform Journalism Virtual Interaktif Kompas". Oleh sebab itu, peneliti ingin menyampaikan rasa terima kasih yang sebesar-besarnya kepada semua pihak yang ikut terlibat dan telah membantu peneliti selama proses penelitian ini berlangsung, yaitu:

1. Bapak Laksono Hari Wiwoho, selaku Wakil Redaktur Pelaksana Kompas.com yang telah meluangkan waktunya untuk diwawancarai oleh penulis.

2. Bapak Albertus Magnus Prestianta, S.I.Kom., M.A., selaku Dosen Fakultas Ilmu Komunikasi Universitas Multimedia Nusantara yang telah meluangkan waktunya untuk menjadi narasumber penulis.

3. Oktavius Popa, William, Imanuel, Putri, Linda selaku mahasiswa/I Universitas Negeri Jakarta yang telah meluangkan waktunya untuk menjadi informan umum penulis.

\section{Daftar Pustaka}

Berning, Nora. (2011). Narrative Journalism in the Age of the Internet: New Ways to Create Authenticity in Online Literary Reportages. Textpraxis 3 (2.2011). http://www.uni-muenster.de/textpraxis/nora-berning-narrative-journalism-inthe-age-of-the-internet, URN:urn:nbn:de:hbz:6-13439431620.

Budianti, Indah, dkk. (2018). Profil Generasi Milenial Indonesia. Jakarta: Kementerian Pemberdayaan Perempuan dan Perlindungan Anak. Diakses dari: https://www.kemenpppa.go.id/lib/uploads/list/9acde-buku-profil-generasimilenia.pdf

Erdiansyah, Paramita. (2016). Entrepreneurship Dan New Media Pada Generasi Muda.https://www.researchgate.net/profile/Sinta_Paramita2/publication/3038 22547_ENTREPRENEURSHIP_DAN_NEW_MEDIA_PADA_GENERASI _MUDA/links/575649af08ae0405a575841b.pdf

Lassila-Merisalo, M. (2014). Publishing Narrative Long-Form Journalism in Digital Environtments. Journal of Magazine \& New Media Research, 15(2). Diambil kembali dari: http://aejmcmagazine.arizona.edu/Journal/Summer2014/LassilaMerisalo .pd. 
Viranda,dkk. (2018). Manajemen Produk Media Kompas.com Untuk Bersaing di Era Generasi Milenial. Universitas Padjajaran, Bandung. Diakses dari: http://journal.unpad.ac.id/kajian-jurnalisme/article/view/21074

Yin, R. K. (2015). Studi Kasus: Desain \& Metode (Ed. 1, Cet. 14 ed.). (M. D.) Yazan, B. (2015). Three Approaches to Case Study Methods in Education: Yin. https://www.kompasiana.com/septyonaka/58ccbalfb37a61730c059dbf/menujulongform-journalism

https://docplayer.info/63977126-Jurnalisme-multimedia-longform-di-media-digitalanalisa-naratif-pada-artikel-tempo-co.html 